\title{
PERLINDUNGAN HUKUM KAWASAN KARST TERHADAP KEGIATAN PERTAMBANGAN KAITANNYA DENGAN PENGELOLAAN LINGKUNGAN (STUDI KASUS PENAMBANGAN BATU GAMPING DI KAWASAN KARST GOMBONG SELATAN, KEBUMEN, J AWA TENGAH)
}

\author{
Wisda Amalia1, Adji Samekto², Eko Sabar Prihatin 3 \\ Program Studi Magister IImu Hukum \\ Fakultas Hukum Universitas Diponegoro
}

\begin{abstract}
ABSTRAK
Kawasan Penambangan Batu Gamping di Gombong Selatan, Kabupaten Kebumen, Jawa tengah, merupakan Kawasan Bentang Alam Karst, yang secara yuridis tidak boleh ditambang, namun faktanya kawasan tersebut masih terus ditambang oleh masyarakat sekitar, sehingga banyak dampak kerusakan lingkungan yang terjadi. Fenomena ini akhirnya memunculkan pertanyaan, mengapa pemerintah daerah belum memberikan perlindungan hukum terhadap Kawasan Karst Gombong secara optimal. Beberapa faktor yang mempengaruhi ketidakoptimalan pemerintah daerah dalam memberikan perlindungan hukum, selain karena faktor ekonomi yang mendominasi, faktor dilematis pemerintah dalam menertibkan para penambang yang hanya menambang skala kecil pun, akhirnya semakin menyebabkan regulasi yang ada tidak berjalan secara optimal. Ditambah, dengan beralihnya kewenangan Izin Pertambangan Rakyat ke provinsi, yang justru semakin mempersulit dan memperlemah pengawasan pemerintah daerah. Realita ini menunjukkan bahwa masih lemahnya penegakan hukum di daerah tersebut, oleh karena itu penting adanya penguatan kembali secara kelembagaan, aturan, serta budaya hukum, sehingga hukum dapat berfungsi dengan baik dan lebih efektif.
\end{abstract}

\section{Kata Kunci : Kawasan karst; Penambangan batu Gamping}

\footnotetext{
${ }^{1}$ Mahasiswa Program Studi Magister IImu Hukum UNDIP

2 Penulis Kedua, Penulis Koresponden

3 Penulis Ketiga
} 


\section{Pendahuluan}

Kawasan karst merupakan bentang alam yang terbentuk dalam kurun waktu ribuan tahun, tersusun atas batuan karbonat (batu kapur/batu gamping) yang mengalami proses pelarutan sedemikian rupa, hingga membentuk kenampakan morfologi dan tatanan hidrologi yang unik dan khas. ${ }^{4}$ Selain menyimpan air, dan memiliki sumber daya alam hayati berupa jenis flora dan fauna, karst juga mengandung sumber daya alam nonhayati, salah satunya ialah batu gamping, yang mana merupakan bahan galian golongan $\mathrm{C}$.

Banyaknya sumber daya alam yang terkandung di dalam kawasan karst, akhirnya menjadikan kawasan tersebut sebagai lahan potensial yang memberikan banyak keuntungan. Namun, bersamaan dengan dampak positif pemanfaatannya, kawasan karst sudah tentu pula menjadi sangat rentan terhadap kerusakan lingkungan.

4 Sari B.Kusumayudha, Hiderologi Karst dan Geometri Fraktal di Daerah Gunungsewu, Adicita Karya Nusa, Yogyakarta, 2005, hlm. 1
Salah satu kawasan karst di Indonesia ialah Kawasan Karst Gombong Selatan di Kebumen, Jawa Tengah. Kawasan Karst Gombong Selatan merupakan salah satu kekayaan alam yang memiliki potensi yang sangat besar di Kebumen. Keberadaan dan besarnya potensi yang terkandung di dalam Kawasan karst Gombong Selatan itulah yang akhirnya pada tahun 2004 ditetapkan oleh Presiden Susilo Bambang Yudhoyono sebagai kawasan eko-karst. ${ }^{5}$ Namun sayangnya, berbagai potensi yang dimiliki kawasan karst Gombong Selatan ini semakin lama semakin menurun bahkan memprihatinkan. Keadaan ini terutama disebabkan oleh semakin maraknya kegiatan penambangan batu gamping yang dilakukan di kawasan tersebut.

Menurut Dinas Lingkungan Hidup Kebumen jelas akan menambah rusaknya lingkungan karst, khususnya gua karst Gombong, habitat tempat sarang burung walet dan kelelawar yang berada di sana, serta menghancurkan fungsi gua karst sebagai penyimpan air.

\footnotetext{
5 Sumber Referensi : Gregorius Magnus zFinesso (editor: Nasru Alam Aziz), "Tambang Liar Ancam Kawasan Karst Gombong

Selatan",http://regional.kompas.com/read/2012/05/21/185045 85/Tambang.Liar.Ancam.Kawasan.Karst.Gombong.Selatan., diakses tanggal 3 September 2015.
} 
Besarnya perkiraan dampak kerusakan terhadap lingkungan karst atas kegiatan pertambangan in realitanya tidak mengurangi kegiatan tambangmenambang, justru sebaliknya beberapa tahun terakhir ini kegiatan penambangan semakin meningkat.

Pertambangan dan lingkungan hidup bagaikan dua sisi dari sekeping mata uang, antara menyejahterakan atau mengorbankan alam sekitar, oleh karena itu, idealnya perlu keseimbangan antara pengelolaan dan kelestarian lingkungan, sehingga kegiatan penambangan yang bernilai ekonomi bagi negara dan masyarakat lokal dapat berjalan, namun tetap tidak merusak kawasan lindung tersebut.

Peraturan Perundang-Undangan No. 32 Tahun 2009 sebagai Undang-Undang payung dari perlindungan dan pengelolaan lingkungan, yang akhirnya memiliki peran penting dalam upaya menganalisis dan memberikan solusi hukum dari kasus penambangan di kawasan karst Gombong selatan ini. UU No.32 Tahun 2009 tersebut menggariskan bahwa:

"perlindungan dan pengelolaan lingkungan hidup adalah upaya sistematis dan terpadu yang dilakukan untuk melestarikan fungsi lingkungan hidup dan mencegah terjadinya pencemaran dan I atau kerusakan lingkungan hidup yang meliputi perencanaan, pemanfaatan, pengendalian, pemeliharaan, pengawasan, dan penegakan hukum". 6

Enam hal yang menjadi ruang lingkup dalam upaya perlindungan dan pengelolaan lingkungan (Pasal 4 UU No. 32 tahun 2009) di atas tersebutlah, yang dapat dijadikan poin penting untuk menganalisis lebih dalam mengenai upaya perlindungan hukum pada kasus pertambangan di kawasan karst Gombong Selatan. Adapun Penulis dalam penelitian ini, lebih menekankan fokus kajiannya pada salah satu aspek, yaitu pengendalian.

Berdasarkan latar belakang yang telah Penulis paparkan di atas inilah, kemudian Penulis rasa perlu mengangkatnya ke dalam sebuah kajian yang berjudul : "Perlindungan Hukum Kawasan Karst terhadap Kegiatan Pertambangan Kaitannya dengan Pengelolaan Lingkungan (Studi kasus Penambangan batu Gamping di Kawasan karst Gombong Selatan, Kebumen, Jawa Tengah).

6 Pasal 1 angka ayat (2) UU No. 32 tahun 2009 Tentang Perlindungan dan Pengelolaan Lingkungan Hidup 


\section{Metode Penelitian}

Penelitian ini menggunakan pendekatan sosiolegal, yaitu pendekatan yang memadukan antara kajian normatif dengan empirik, artinya dalam pengkajiannya mengkonsepsikan hukum sebagai norma, sekaligus sebagai realitas. ${ }^{7}$ Hukum dipahami sebagai peraturan dan sekaligus sebagai sub-sistem dalam masyarakat, yang keberlakuannya mempengaruhi dan dipengaruhi sub-sistem lainnya. ${ }^{8}$

Sementara spesifikasi penelitian yang digunakan adalah penelitian yang bersifat kualitatif, karena dalam penelitian ini yang diutamakan adalah kedalaman data, bukan dari banyaknya data, sehingga dalam penelitian ini sangat diperlukan narasumber dan penelitian secara langsung. ${ }^{9}$ Berdasarkan spesifikasi inilah, maka metode pengumpulan data yang digunakan berupa wawancara dan studi pustaka.

7 Adji Samekto, Pergeseran Pemikiran Hukum dan Era Yunani Menuju Postmodernisme, Penerbit Konstitusi Press, Jakarta, 2015, hlm. 187.

8 Adji Samekto, Pemahaman Dasar Metode Penelitian Hukum, Op.Cit., hlm. 4.

9 M. Djunaidi Ghony, dan Fauzan Almanshur, Metodologi Penelitian Kualitatif, Ar-Ruzz media, Yogyakarta, 2012, hlm. 18.
Sementara untuk teknik analisis data yang digunakan dalam penelitian ini ialah preskriptif analisis, yang bersifat induktif. Hal ini mengingat, bahwa penelitian hukum menurut Bernard Arif Sidharta, hukum mempunyai peran menyelesaikan problem konkrit dalam masyarakat, sehingga sifat penelitian-penelitian hukumnya lebih cenderung bersifat preskriptif. Preskriptif analisis ialah prosedur penelitian yang dimaksudkan untuk mendapatkan saran-saran mengenai apa yang harus dilakukan untuk mengatasi masalah tertentu. ${ }^{10}$

\section{Pembahasan}

\section{A. Faktor Kurang Optimalnya Pemerintah Daerah Dalam Melakukan Perlindungan Hukum Terhadap Kawasan Karst Gombong Selatan dari Kegiatan Pertambangan}

Terkait kurang optimalnya pemerintah daerah dalam melakukan perlindungan hukum, sebagaimana hasil wawancara yang dilakukan Penulis terhadap beberapa sumber (baik pemerintah daerah, maupun instansi pemerintah yang bertanggung jawab di bidang terkait),

${ }^{10}$ Amiruddin dan Zainal Asikin, Pengantar Metode Penelitian Hukum, Raja Grafindo Persada, Jakarta, 2004, hlm.48. 
dapat diketahui bahwa terdapat beberapa faktor yang mempengaruhi.

Pertama, faktor yang berasal dari masyarakat Kawasan karst Gombong Selatan, diantaranya seperti ; masih minimnya kesadaran masyarakat (penambang) di Kawasan Karst Gombong Selatan untuk berizin. Hal ini tentu merupakan salah satu faktor yang cukup rumit pemecahannya, sebab menyangkut aspek kesadaran seseorang. Oleh karena itu untuk mengkajinya tentu harus dilihat dari berbagai aspek, baik sosial, ekonomi, maupun pendidikan. Sebagaimana dikemukakan oleh William J. Chambliss dan Robert B. Seidman, dalam Teorinya tentang Berlakunya Hukum.

Menurut Chambliss dan Seidman ${ }^{11}$, secara garis besar bekerjanya hukum dalam masyarakat akan ditentukan oleh beberapa faktor, artinya keberhasilan pelaksanaan suatu peraturan perundang-undagan di dalam masyarakat, sangat tergantung banyak faktor.

11 Pendapat Chambliss dan Seidman dikutip dari Buku Syahrul Machmud, Penegakan Hukum Lingkungan Indonesia, Penegakan Hukum Administrasi, Hukum Perdata, dan Hukum Pidana Menurut Undang-Undang No.32 Tahun 2009, Graha IImu, Yogyakarta, 2012, hlm. 164.
Faktor tersebut meliputi keseluruhan komponen sistem hukum, yaitu faktor substansial, faktor struktural dan faktor kultural. Berdasarkan teori inilah, kemudian dapat kita lihat pada kasus maraknya penambangan ilegal pada kawasan karst Gombong Selatan, bahwa banyak faktor yang mempengaruhi berlakunya hukum di kawasan tersebut. Bisa jadi masyarakat penambang ilegal yang masih belum sadar akan pentingnya berizin itu, disebabkan faktor ekonomi atau pendidikannya yang rendah, sehingga pengetahuan mengenai perizinan dan dampak yang ditimbulkan masih sangat kurang.

Faktor kedua yakni penambang ilegal merupakan penduduk yang secara turun temurun tinggal di Kawasan Karst Gombong selatan tersebut, sehingga mereka merasa bahwa lahan yang mereka tambang adalah milik mereka sendiri. Hal ini diakui oleh Kabid Pengembangan Infrastruktur dan Wilayah, Bapedda Kabupaten Kebumen, Joni Hermawan, ${ }^{12}$ menjadi dilema tersendiri dalam menegakan aturan. Sebab ratarata alasan yang diutarakan para penambang ilegal tersebut ialah untuk memenuhi kebutuhan hidup mereka sehari-hari, bukan bussines oriented.

\footnotetext{
12 Berdasarkan hasil wawancara dengan Kepala Bidang Pengembangan Infrastruktur dan Wilayah Bappeda, Joni Hermawan (Kebumen, 30 November 2015)
} 
Berdasarkan pertimbangan itulah, akhirnya para penambang di Kawasan Karst Gombong yang seharusnya tidak boleh ditambang, diberi toleransi untuk tetap menambang, meski tanpa izin.

Faktor kurangnya kesadaran pemahaman tentang pentingnya melindungi kawasan lindung karst pun, menjadi salah satu yang menyebabkan upaya perlindungan hukum pemerintah daerah kurang terrealisasikan dengan baik. Meski berulang kali dilakukan sosialisasi, pihak Bapedda, KLH, ESDM maupun Kehutanan, berusaha menghimbau agar para penambang batu gamping mau beralih profesi ke lain sektor, seperti pertanian atau peternakan, namun, mereka masih sulit untuk beralih dari sektor tambang. Pola pikir kegiatan penambangan merupakan matapencaharian yang sangat efektif untuk mendapatkan keuntungan secara langsung, dirasa lebih menjanjikan dibandingkan sektor lain yang harus memakan waktu lama untuk menikmati hasilnya.

Faktor lain yang juga semakin mempengaruhi ketidakoptimalana pemerintah daerah dalam menegakan aturan hukum ialah kurangnya kesadaran pemahaman masyarakat tentang pentingnya melindungi kawasan lindung karst. Sebagian masyarakat penambang lebih mementingkan kesejahteraan ekonomi mereka, ketimbang memperhatikan kelestarian kawasan lindung karst dan lingkungan di dalamnya, baik yang bersifat hayati maupun non-hayati. Ini menguatkan apa yang pernah disampaikan oleh Edith Brown Weiss mengenai teori "keadilan antargenerasi"nya. Edith Brown Weiss sebagaimana dikutip oleh Adji Samekto13, menyatakan bahwa secara garis besar ada tiga tindakan generasi dulu dan sekarang yang sangat merugikan generasi mendatang di bidang lingkungan, yaitu :

(1) konsumsi yang berlebihan terhadap sumber daya alam yang berkualitas, yang membuat generasi mendatang harus membayar mahal untuk mengkonsumsi sumber daya yang sama;

(2) pemakaian sumber daya alam yang saat ini belum diketahui manfaat terbaiknya secara berlebihan, sangat merugikan kepentingan generasi mendatang, karena mereka harus membayar in-efisiensi dalam penggunaan sumber daya alam tersebut oleh generasi dulu dan sekarang;

13 Adji Samekto, Kapitalisme, Modernisme, dan Kerusakan Lingkungan, Pustaka Pelajar, Yogyakarta, 2005, hlm. 74. 
(3) pemakaian sumber daya alam secara habishabisan oleh generasi dulu dan sekarang membuat generasi mendatang tidak memiliki keragaman sumber daya alam yang tinggi. Dari ketiga penyebab kerusakan sumber daya alam tersebut, maka dapat dilihat dari apa yang terjadi di Kawasan Karst Gombong Selatan ini. Kurangnya kesadaran akan pentingnya karst sebagai kawasan lindung akan berdampak buruk pada generasi selanjutnya.

Faktor terakhir dari masyarakat, yaitu tidak mau bersusah-payahnya masyarakat penambang dalam mengurus proses perizinan. Menurut Kabid PIW Bappeda, terkait pemanfaatan kawasan karst, sebenarnya ada wilayah karst yang bisa ditambang, namun harus dengan izin. Kawasan karst tersebut yaitu Kawasan Karst Gombong Selatan yang berada di luar Kawasan Bentang Alam Karst (KBAK) yang telah ditetapkan Kepmen ESDM No. 3873 K/40/MEM/2014 tentang Penetapan Kawasan Bentang Alam Karst Gombong. Hal ini dikuatkan oleh informasi dari Kabid Pemulihan Lingkungan Hidup Kantor Lingkungan Hidup Kabupaten Kebumen, yang menjelaskan bahwa tidak semua kawasan karst yang termasuk dalam tiga kecamatan (Buayan,Ayah dan Rowokele) itu merupakan kawasan yang tidak boleh ditambang.
Kawasan karst yang tidak lagi mengalami proses karstifikasi dan tidak ada ekosokarst dan endokarstnya boleh ditambang. ${ }^{14}$ Kendati demikian, masyarakat masih susah untuk ditertibkan, ditambah dengan berlakunya UU NO.23 tahun 2014 tentang Pemerintahan Daerah, yang mana mengalihkan kewenangan Izin Pertamabangan Rakyat ke provinsi. Hal ini justru semakin memperbesar angka ketidakmauan penambang dalam berizin, sebab banyaknya kendala yang dirasakan mareka ketika harus berizin dari daerah ke provinsi.

Selain faktor yang berasal dari masyarakat, faktor yang berasal dari pemerintah itu sendiri pun tidak kalah berpengaruhnya terhadap ketidakoptimalan kinerja mereka. Lemahnya penegakan hukum dari pemerintah, sebab adanya unsur dilematis dalam menerapkan aturan hukum, menjadi salah satu faktor yang sangat berpengaruh. Pemerintah cenderung memberikan toleransi terhadap masyarakat penambang yang berdalih menambang untuk kebutuhan sehari-hari di Kawasan Bentang Alam Karst tersebut.

1414 Hasil wawancara Kabid Pemulihan Lingkungan Hidup, Kantor Lingkungan Hidup Kabupaten Kebumen, Siti Duhrotul Yatimah, (Kebumen, 1 Februari 2016) 
Pengaruh atas berlakunya UU No. 23 Tahun 2014 tentang Pemerintahan Daerah, dimana kewenangan perizinan beralih dari daerah ke provinsi pun, menjadi salah satu kendala pemerintah dalam menegakan aturan hukum, salah satunya dalam hal pengawasan. Menurut Kabid ESDM, sejak adanya UU tersebut, maka terkait pengawasan pertambangan, yang melakukan adalah langsung dari pusat, pemerintah daerah hanya membantu. Pemerintah daerah tidak lagi memiliki kewenangan terkait kegiatan pertambangan yang berada di daerah. Bahkan menurutnya, Oktober 2016 ini, semua data dan arsip-arsip yang dimiliki pihak ESDM Kebumen terkait pertambangan, sudah harus diserahkan ke provinsi. Hal ini tentu akhirnya semakin memperlemah penegakan hukum terkait penambangan ilegal di Kawasan Karst Gombong Selatan. ${ }^{15}$

15 Hasil wawancara Kabid ESDM Dinas SDA ESDM
Kabupaten Kebumen, Endah Dwi Yantiningsih, (Kebumen, 21 Maret 2016)

\section{B. Upaya Perlindungan Hukum Pemerintah Daerah dalam Rangka Pengelolaan Kawasan Karst Gombong}

Sebagai upaya perlindungan hukum yang dilakukan pemerintah dalam rangka pengelolaan Kawasan Karst Gombong Selatan ialah dengan menegakan aturan-aturan terkait Kawasan Karst Gombong Selatan. Adapun regulasi-regulasi terkait diantaranya berupa UU No. 32 Tahun 2009 tentang Perlindungan dan Pengelolaan Lingkungan Hidup, Perda Provinsi Jawa Tengah No. 6 Tahun 2010 tentang RTRW Provinsi Jawa Tengah, Perda Kabupaten Kebumen No. 23 tahun 2012 tentang RTRW Kabupaten Kebumen, serta Kepmen ESDM Nomor 3873 K / 40 / MEM / 2014, tentang Penetapan Kawasan Bentang Alam Karst (KBAK) Gombong. Namun, dalam realitanya beberapa aturan hukum tersebut di lapangan masih sangat sulit sekali diterapkan. Masih banyak pelanggaranpelanggaran yang dilakukan masyarakat sekitar, hingga akhirnya berdampak pada kerusakan lingkungan karst, seperti semakin menurunya kualitas dan kuantitas air yang terkandung di dalamnya, rusaknya lahan karst, terganggunya ekosistem di kawasan tersebut, serta terjadinya pencemaran udara sebab asap yang dihasilkan dari proses pembakaran gamping tersebut. 
Kepmen ESDM No. 3873 K / 40 / MEM / 2014 yang menyebutkan jumlah luasan geologi dan hiderologi KBAK Gombong sebesar 40, 89 km², dan ketentuan sanksi-sanksi di dalam UU No.32 tahun 2009, Perda RTRW Jawa tengah maupun Kebumen pun nyatanya tidak cukup "menggentarkan" penambang ilegal di kawasan tersebut.

Upaya-upaya pengendalian dan pengelolaan oleh pemerintah daerah nyatanya juga telah diberikan. Menurut pemerintah daerah, mereka secara rutin, bekerjasama dengan instansi-instansi pemerintahan yang bertanggung jawab di bidang terkait, mengadakan sosialisasi-sosialisasi dan pembinaan terhadap masyarakat di 3 kecamatan yang masuk dalam Kawasan karst Gombong Selatan tersebut. Sosialisasi dan pembinaan ini terutama dimaksudkan agar masyarakat beralih profesi, dari sektor tambang ke sektor lainnya yang lebih ramah lingkungan. Upaya-upaya tersebut ternyata tidak cukup mengendalikan angka penambangan ilegal di kawasan tersebut, mengingat semakin hari justru kegiatan penambangan batu gamping semakin marak terjadi. Kendati masyarakat sekitar Kawasan Karst mengetahui mana saja wilayah karst yang termasuk dalam KBAK dan mana yang tidak, mereka tetap menambang kawasan tersebut, bahkan ironisnya dengan minimnya kesadaran akan pentingnya lingkungan dan pembangunan yang berwawasan lingkungan, sebagian dari mereka menambang dengan menggunakan bahan-bahan peledak yang sudah tentu semakin memperparah kawasan lindung tersebut.

Berdasarkan fakta-fakta di atas, maka menurut Penulis, penting adanya penguatan kembali secara kelembagaan, aturan (khususnya terkait pengelolaan Kawasan Karst), serta kultur atau budaya taat hukum di daerah tersebut. Hal ini agar hukum dapat berfungsi dengan baik dan berjalan lebih efektif.

Penguatan kelembagaan ini pun tentunya tetap dengan merujuk asas-asas hukum yang telah diatur dalam Pasal 2 UU No.32 tahun 2009 tentang perlindungan dan Pengelolaan Lingkungan Hidup, sehingga diharapkan akan lebih terwujud upaya perlindungan hukum, baik secara preventif maupun secara represif, yang optimal dan dapat memberikan keadilan, antar generasi khususnya, serta kepastian hukum bagi Kawasan Bentang Alam Karst.

Apabila secara kelembagaan, aturan dan budaya hukum di daerah tersebut kuat, seluruh elemen menyadari dan taat pada hukum yang berlaku, maka akan sangat mungkin kiranya perlindungan dan pengelolaan lingkungan Kawasan Karst Gombong yang berkelanjutan dan berwawasan lingkungan terwujud dengan baik. 


\section{Simpulan dan Saran}

\section{A. Simpulan}

1. Kurang optimalnya pemda dalam melakukan perlindungan hukum terhadap Kawasan karst Gombong Selatan dari kegiatan pertambangan, dipengaruhi oleh beberapa faktor, antara lain : faktor dari dalam masyarakat/sosial, seperti masih minimnya kesadaran masyarakat untuk berizin, mayoritas penambangan adalah penduduk asli kawasan karst tersebut, kurangnya kesadaran masyarakat tentang pentingnya melindungi kawasan lindung karst, serta masyarakat yang tidak mau bersusah payah mengurus terkait izin pemanfaatan batu gamping di luar Kawasan Bentang Alam Karst yang boleh ditambang, ditambah dengan beralihnya kewenangan perizinan pertambangan rakyat ke provinsi. Adapun faktor yang menyebabkan ketidakoprimalan perlindungan hukum oleh pemerintah daeraha ialah disebabkan dari dalam peemerintahan itu sendiri, dimana adanya unsur dilematis pemerintah dalam menerapkan aturan hukum di Kawasan Karst Gombong tersebut,sehingga masih ada toleransi yang diberikan bagi penambang yang menambang untuk kebutuhan sehari-hari. Selain itu pengaruh atas berlakunya
UU No. 23 Tahun 2014 tentang Pemerintahan Daerah yang mengalihkan kewenangan izin ke provinsi, akhirnya semakin mempersempit ruang gerak pemerintah daerah. Mereka sudah tidak memiliki peran yang signifikan terkait kegiatan pertambangan di daerah.

2. Sebagai upaya perlindungan hukum dalam rangka pengelolaan Kawasan Karst Gombong, maka selain dengan menegakan aturan-aturan terkait perlindungan Kawasan Karst Gombong, yang berupa UU No. 32 Tahun 2009 tentang Perlindungan dan Pengelolaan Lingkungan Hidup, Perda Provinsi Jawa Tengah No. 6 Tahun 2010 tentang RTRW Provinsi Jawa Tengah, Perda Kabupaten Kebumen No. 23 tahun 2012 tentang RTRW Kabupaten Kebumen, serta Kepmen ESDM Nomor 3873 K I 40 / MEM / 2014, tentang Penetapan Kawasan Bentang Alam Karst (KBAK) Gombong, pemerintah juga telah berupaya dengan secara rutin mengadakan sosialisasi dan pembinanaan kepada masyarakat di 3 kecamatan Karst gombong tersebut. pembinaan lebih dimaksudkan agar masyarakat beralih profesi dari tambang ke sektor usaha yang lain, namun nyatanya upaya ini belum banyak membuahkan hasil. Oleh karena itu penting adanya penguatan kembali secara kelembagaan, aturan 
(khususnya terkait pengelolaan kawasan karst), serta kultur atau budaya taat hukum di kawasan tersebut, sehingga hukum dapat berfungsi dengan baik dan lebih efektif. Penguatan kelembagaan ini juga tentunya dengan merujuk pada asas-asas hukum yang telah diatur dalam Pasal 2 UU No. 32 tahun 2009, sehingga diharapkan akan lebih terwujud upaya perlindungan hukum, baik secara preventif maupun represif yang efektif dan memberikan kepastian hukum bagi Kawasan Bentang Alam Karst Gombong.

\section{B. Saran}

\section{1) Bagi Masyarakat}

Kepekaan masyarakat dalam memeahami hak dan kewajibannya khususnya untuk berizin dan menambang dengan bijak masih kurang. Oleh karena itu, agar terwujud pembangunan berkelanjutan yang seimbang dan berwawasan lingkungan, maka perlu kiranya masyarakat lingkar tambang untuk mengubah pola pikirnya dalam memanfaatkan karst yang merupakan sumber daya alam yang tidak dapat diperbaharui agar tidak semena-mena dan tetap dengan memperhatikan prinsip-prinsip ekologi dalam pemanfaatannya.
2) Bagi Pemerintah Daerah

Untuk menciptakan kepastian dan penegakan aturan hukum yang baik dan tegas terkait perlindungan dan pengelolaan Kawasan Karst Gombong ini, maka sangat diperlukan adanya pembenahan secara kelambagaan. Lembaga harus lebih memperkuat struktur di dalamnya, agar aturan hukum yang berlaku dapat diterapkan secara lebih tegas dan optimal. Pembenahan di bidang aturan pun sangat diperlukan, mengingat perlindungan hukum secara represif di dalam perda tampaknya masih kurang. Penumbuhan kultur atau budaya taat hukum di kawasan tersebut pun tidak kalah pentingnya di sini. Dengan adanya budaya hukum yang kuat, maka tentu hukum terkait perlindungan dan pengelolaan Kawasan Karst Gombong akan dapat berjalan lebih efektif dan optimal.

3) Bagi Akademik

Fenomena ini semakin memperkuat pentingnya pendekatan sosio-legal dengan analisis yang bersifat induktif dalam kajian hukum, mengingat analisis induktif sangat mengandalkan faktafakta yang terjadi di lapangan. Fakta-fakta yang terjadi di lapangan tersebut, sebenarnya terdapat masukan-masukan yang berguna bagi penyempurnaan aturan-aturan yang sudah ada terkait dengan pengelolaan kawasan karst. 
Inilah yang kemudian membuktikan, bahwa pentingnya sosio-legal dan analisis induktif, terutama dalam dunia akademik.

\section{Daftar Pustaka}

\section{Buku}

Amiruddin dan Zainal Asikin, 2004,

Pengantar Metode Penelitian Hukum, Jakarta, Raja Grafindo Persada.

Ghony, M. Djunaidi dan Fauzan Almanshur, 2012,

Metodologi Penelitian Kualitatif, Yogyakarta, Ar-Ruzz media.

Kusumayudha, Sari B., 2005,

Hidrogeologi Karst dan Geometri Fraktal di daerah Gunung Sewu, Yogyakarta, Adicita karya Nusa.

Samekto, Adji, Pemahaman Dasar Metodologi

Penelitian Hukum, disampaikan sebagai materi perkuliahan kelas akhir pekan Magister IImu Hukum Universitas Diponegoro, tanggal 16 Oktober 2015. , 2015, Pergeseran Pemikiran

Hukum di Era Yunani menuju Postmoderisme, Jakarta, Konstitusi Press.

2005, Kapitalisme,

Modernisasi dan Kerusakan Lingkungan, Yogyakarta, Pustaka Pelajar.

Machmud, Syahrul, 2012, Penegakan Hukum
Lingkungan Indonesia, Penegakan Hukum Administrasi, Hukum Perdata, dan Hukum Pidana Menurut Undang-Undang No.32 Tahun 2009, Yogyakarta, Graha IImu.

\section{Peraturan Perundang-Undangan}

Undang-Undang No 32 Tahun 2009 tentang Perlindungan dan Pengelolaan Lingkungan Hidup.

Undang-Undang No.23 Tahun 2014 tentang Pemerintahan Daerah.

Peraturan Daerah Provinsi Jawa Tengah Nomor 6 Tahun 2010 tentang Rencana Tata Ruang Wilayah Provinsi Jawa Tengah Tahun 20092029.

Peraturan Daerah Kabupaten Kebumen Nomor 23 Tahun 2012 tentang Rencana tata Ruang Wilayah Kabupaten Kebumen Tahun 20112031.

Keputusan Menteri ESDM No.3873 K/ 40 / MEM / 2014 terkait Perubahan Keputusan Menteri ESDM No. 3043 K / 40 / MEM / 2004 tentang Penetapan Kawasan Bentang Alam Karst (KBAK) Gombong.

\section{Website}

Gregorius Magnus Finesso (editor: Nasru Alam Aziz), "Tambang Liar Ancam Kawasan Karst Gombong 
Selatan",http://regional.kompas.com

/read/2012/05/21/18504585/Tamba

ng.Liar.Ancam.Kawasan.Karst.Gom

bong.Selatan., (diakses tanggal 3 September

2015. 